\title{
Job satisfaction, life orientation and perception of family role - Comparison between women employed in public sector and in economy
}

\author{
UDK: 338.1:061.1EU(045)
}

Eva Boštjančič

University of Ljubljana, Faculty of Arts, Department of Psychology, Slovenia eva.bostjancic@ff.uni-lj.si

\begin{abstract}
Our scope of interest in this article is employed women in Slovenia working in public sector (state administration, education and healthcare) and in economy. Working women's various roles today may lead to conflict or enrichment. This study seeks to determine the connection between their multiple roles, life orientation, and life satisfaction. The study was carried out through Internet questionnaires and surveyed 1,298 working women. Their average age was 35.6 years. A total of $43 \%$ of participants had at least college degree. The results show that working women are at least satisfied with their leisure time and most satisfied with their maternal role. The most satisfied women work in pharmaceuticals and healthcare, and the least satisfied work in the state administration sector. Women with multiple roles are more satisfied with their maternal role but less satisfied with their partners and leisure time. They are also more optimistic.
\end{abstract}

Key words: women, public sector, work, role, life orientation, life satisfaction

JEL: J0, J53, J59, J69

\section{Introduction}

The twenty-first century is presenting new challenges for working women and men alike. This paper mainly focuses on the role of working women engaged in various social and personal roles. The statistical data are 
Eva Boštjančič

Job satisfaction, life orientation

and perception of family role

quite revealing. According to the Slovenian Statistical Office (Vertot, 2008) $61.8 \%$ of women were employed, which is above the EU (57.2\%). The share of the population enrolled in tertiary-level education is increasing. Among those enrolled in two-year vocational colleges, three-year junior colleges, and undergraduate programs, a full $58.3 \%$ are women. In most EU countries parental leave is available for those who have worked for their current employer for certain period of time. In Slovenia a mother gets 100\% paid maternity leave for 12 months and a father gets 11 days paid. There is also an official policy for part-time work for mothers with young children. The pre-school care is appropriately organized but not for free - parents pay contribution based on their average family's incomes. However, the position of women on the labor market does not reflect this: more men than women are employed, more women than men are unemployed, and women earn 15\% less per hour than men and have more difficulties being promoted than men. As a result, the European Commission adopted the 2006-2010 Roadmap for Gender Equality, followed by the European Council's Pact for Gender Equality, both proof that the EU is actively pursuing genuine gender equality.

In Slovenia the public sector was introduced in 1990s and it has been growing since than. The employment share of all employees in Slovenia from 1999 to 2007 increased in public sector from 19,1 to 20,5\%. Almost two-thirds of employees in this sector are women. In general, the public sector is characterized by relatively higher educated and professional qualifications as the other major sectors of the workforce (Malačič, 2009). Comparing it to the economy sector different rules, different goals and also different ways of motivation are present and that is the reason to include this population into our research.

Women and employment. Employed women are mentally healthier (Barnett \& Baruch, 1985) and in comparison to unemployed women they less often develop psychopathological symptoms and increased blood pressure when faced with stressful events (cf. studies by Brown, Bhrolcrain, \& Harris and by Hauenstein, Kasl, \& Harburg, as cited in Baruch, Biener, \& Barnett, 1987). Some studies have shown that employed women are less depressed than unemployed ones (cf. studies by Aneshensel and by Kandel, Davies, \& Ravies, as cited in Barnett \& Hyde, 2001).

Women and career. After examining literature from the past fifteen years, Stoltz-Loike (1992) identified four factors that influence women's careers: the husband's view of his wife's job, financial prospects, household work, and the 
woman's character. During their careers, both men and women can climb the corporate ladder; higher positions offer more positive opportunities for women: promotion, a sense of responsibility, self-respect, and financial independence (Argyle, 1999; Crompton \& Lyonette, 2004). At the same time, such positions positively affect women's roles in their social, economic, and private lives (Ufuk \& Oezgen, 2001). Businesswomen often suffer due to conflicts arising from the different roles they play as professionals and within their families (Ufuk \& Oezgen, 2001). If they have to choose between different roles, they more often spend time on their family and work, leaving less time for themselves and relaxation (Stevenson, 1988).

Women and the family (partner, marriage, children). Marriage is a great source of life satisfaction among adults (Argyle, 1999), and so divorce could worsen women's situation. Changes in professional roles exert a stronger influence on the mental health of women without a family (Barnett et al., 1992). Similarly, women with preschool children face less stress if they are employed (cf. a study by Kessler \& McRae, as cited in Barnett \& Hyde, 2001). Some studies (Schoon et al., 2005) point out that being a parent does not significantly correlate with life satisfaction. However, for divorced women, the combination of parenthood and employment correlates with low life satisfaction. Divorced women tend to be more satisfied when childless.

Two theories' perspectives on the role of working women. Most women play several roles in their adult lives. These roles mix with their private (mother, wife, and housewife) or professional (employee, manager, or director) lives. In the past, the relations between roles have mostly been studied through the prism of negative consequences (Barnett, 1998; Greenhaus \& Parasuraman, 1999; Haas, 1999). Nevertheless, modern trends are establishing a different, positive take on this; more precisely, how a combination of different roles enriches women's development (Kirchmeyer, 1992; Rothbard, 2001), positively strengthens it (Crouter, 1984; Grzywacz, 2000; Sumer \& Knight, 2001), stimulates it (Ruderman et al., 2002; Tiedje et al., 1990), and enables it (Frone, 2003; Tompson \& Werner, 1997; Wayne, Musisca, \& Fleesen, 2004).

Gove (1984) and Schoon, Hansson, and Salmela-Aro (2005) advocate the theory of stressful roles. They argue that the combination of having to raise children and work at the same time has negative repercussions on women's health and wellbeing. They claim that an individual simply cannot reconcile work and family (cf. a study by Farmer, as cited in Schoon et al., 2005). Divid- 
Eva Boštjančič

Job satisfaction, life orientation

and perception of family role

ing time between children and work can lead to role conflict and put pressure on women, leading to disease and stress. Women that feel their roles are conflicting are more depressed and less satisfied with their parenting role (Tiedie et al., 1990). On the other hand, the accumulation theory argues that multiple roles generally have a positive influence on a person's life satisfaction, wellbeing, and health (cf. studies by Helson, Elliott, \& Leigh, Lahelma, Arber, Kivelä, \& Roos, and Sieber, as cited in Schoon et al., 2005). Researchers believe that the satisfaction obtained from different roles (worker, partner, and parent) outweighs potential stress. Paid work outside the home enables additional social contacts and professional challenges, and contributes to better selfesteem and financial independence. Reconciliation of parenthood with work helps a person find satisfaction in one area of life when there are problems in another (cf. a study by Fokkema, as cited in Schoon et al., 2005). The theory of role accumulation has been confirmed by several studies that have shown that men and women engaged in different social roles experience fewer physical and psychological problems connected to stress and report feeling better than individuals engaged in fewer roles (cf. studies by Barnett \& Marshall, Crosby \& Jaskar, and Thoits, as cited in Barnett \& Hyde, 2001). Higher life satisfaction is linked to full-time employment (Schoon et al., 2005) and paid work (Argyle, 1999; War, 1999).

Based on numerous studies and interesting findings so far, three research hypothesis were formed regarding employed Slovenian women:

$\mathrm{H}_{1}$ : Women employed in public sector are less satisfied at the workplace than other employed women.

$\mathrm{H}_{2}$ : Women's life orientation - optimism (Scheier, Carver and Bridges, 1994) is positively associated to their perception of career, children, and perception of partner's role.

$\mathrm{H}_{3}$ : Positive association between the multiple roles women play and life orientation (optimism) and life satisfaction (Diener, Emmons, Larsen and Griffin, 1985). 


\section{Method}

Participants. The study included 1,298 employed Slovene women, whose average age was 35.6 years $(S D=8)$. The youngest participant was 19 and the oldest 64 . On average, the participants had been employed for 12 years (SD = $7,6)$. The majority was married $(48 \%)$ or with a partner $(35 \%), 12 \%$ were single, and $5 \%$ divorced or widowed. $43 \%$ had a two-year vocational college, three-year junior college, or undergraduate education, $16 \%$ had a postundergraduate certificate, master's degree, or $\mathrm{PhD}, 23 \%$ had completed high school only and $18 \%$ primary school only. Regarding their area of employment, the sample was heterogeneous: $49 \%$ worked in economy and $51 \%$ in public sector $(24 \%$ in state administration, $19 \%$ in education, $3 \%$ in healthcare, and $5 \%$ in other fields).

Tools. Demographic data on the participants were collected in the first part of the questionnaire. The second part starts with check-list of 20 different suggestions of roles that one woman could play in her life and continued with questions on satisfaction with various roles (motherhood, hobbies and leisure time, employment, and partners). A scale from 1 to 5 was used for selfassessment ( $1=$ I am not satisfied at all, $5=$ I am very satisfied).

The Scheier, Carver, and Bridges (1994) Revised Life Orientation Test (LOT-R) focused on and measured life orientation (optimism/pessimism). This test includes ten items describing optimism and pessimism, of which only six are later assessed (e.g., If something can go wrong for me, it will) while four are fillers. Participants rate items on a five-point scale $(1=$ strongly agree, $5=$ strongly disagree). The test's internal reliability is 0.78 (Scheier, Carver, \& Bridges, 1994) and 0.72 for the present study. The Satisfaction with Life Scale (SWLS) followed. This was developed by Diener, Emmons, Larsen, and Griffin (1985) to measure participants' global assessment of their quality of life according to personal criteria. The scale is comprised of five items (e.g., In most ways my life is close to my ideal). The participant answers on a seven-point scale $(1=$ strongly disagree, 7 = strongly agree). Cronbach's $\alpha$ equals 0.88 .

Procedure. Data collection for the study took place in July and August 2008. The questionnaire was available on-line and the beginning distributed via e-mail to about 50 different e-mails of employed women in Slovenia, in business and in education. Participating women forwarded it further to others - friends, peers, relatives. Anyone could participate who has got that e-mail. 


\section{Eva Boštjančič \\ Job satisfaction, life orientation and perception of family role}

\section{Results}

Satisfaction. Women are most satisfied with their parental (maternal) role. On average, they rate their satisfaction as 4.3 (on a scale of 1 to 5). They are least satisfied with their leisure time, for which the average is 3.4. Career satisfaction was rated at 3.6 and partner satisfaction 4.2. Statistically significant differences were revealed only for career $(F(4,1258)=3.62 ; p<0.01)$ by area of employment. Assessing work satisfaction the highest grade gave women employed in healthcare and pharmaceuticals $(M=3.89 ; S D=0.98)$, followed by women in education ( $\mathrm{M}=3.81$; $\mathrm{SD}=0.92$ ) and business $(\mathrm{M}=3.58$; $\mathrm{SD}=$ 0.98). The least satisfied are women in state administration $(M=3.56 ; S D=$ 0.96) and the Hypothesis 1 is only partly confirmed.

With regard to the different hierarchical positions of women in organizations, they chose between three positions currently held in the organization: executive, manager, or employee. The most satisfied women are executives (Figure 1), followed female managers, whereas the least satisfied are women in non-managerial jobs $(F(2,1279)=31.15 ; p<0.01)$.

Figure 1: Association between position and career satisfaction

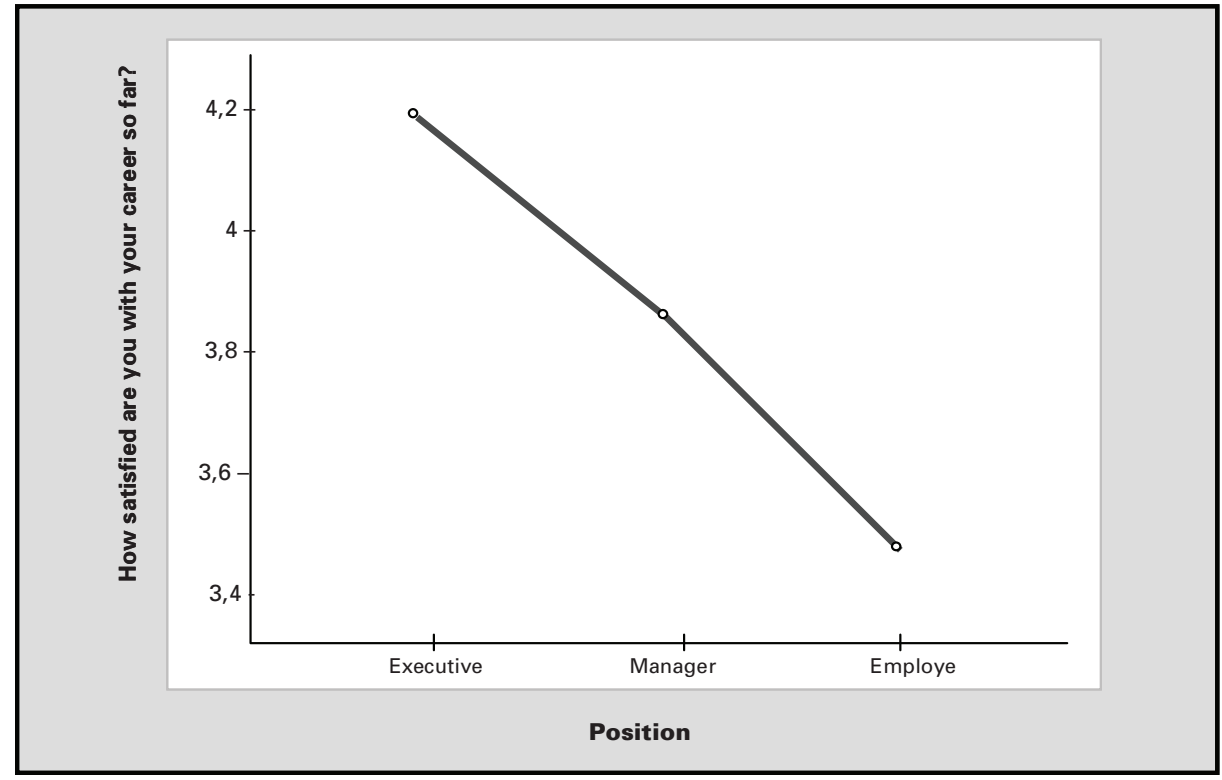


Eva Boštjančič

Job satisfaction, life orientation and perception of family role

Compared with managers and employees are female executives also the most satisfied with their lives (Figure 2); the opposite is true for female employees $(F(2,1093)=7.24 ; p<0.01)$.

Figure 2: Association between position and life satisfaction

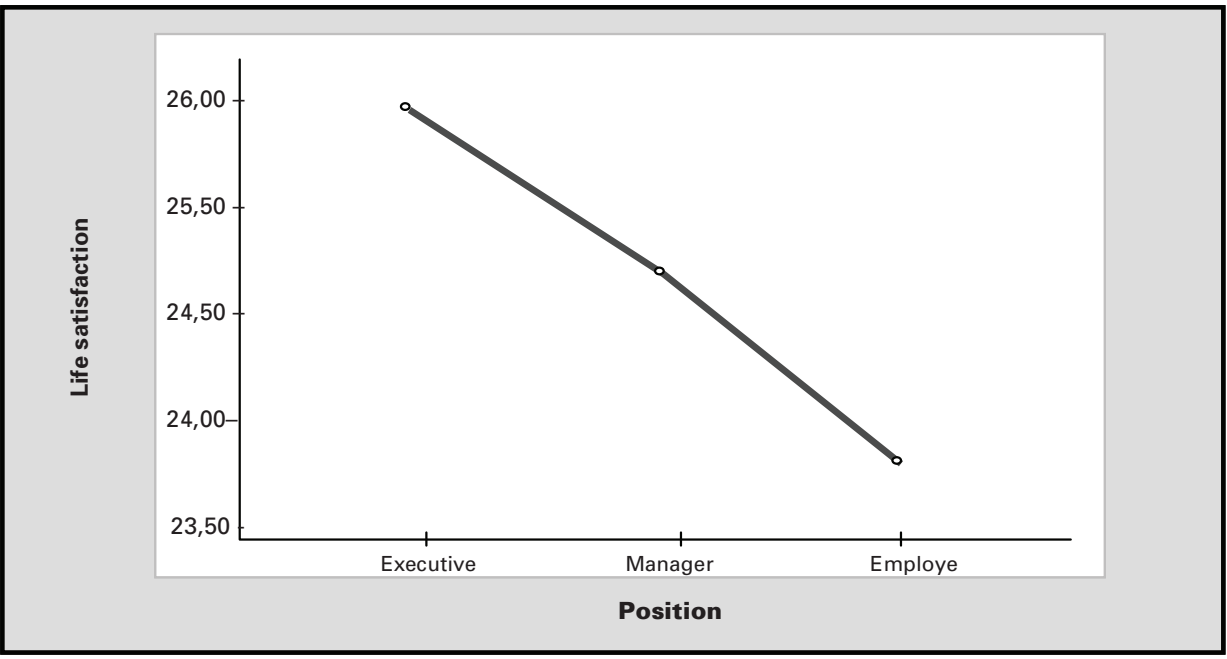

Although the graph slope in Figure 3 is rising, it points out to a high level of optimism among executives, which diminishes with lower positions $(F(2,1080)=4.75$; $p$ $<0.01$ ). This finding supports the first part of established hypothesis $\mathrm{H}_{2}$.

Figure 3: Association between position and life orientation

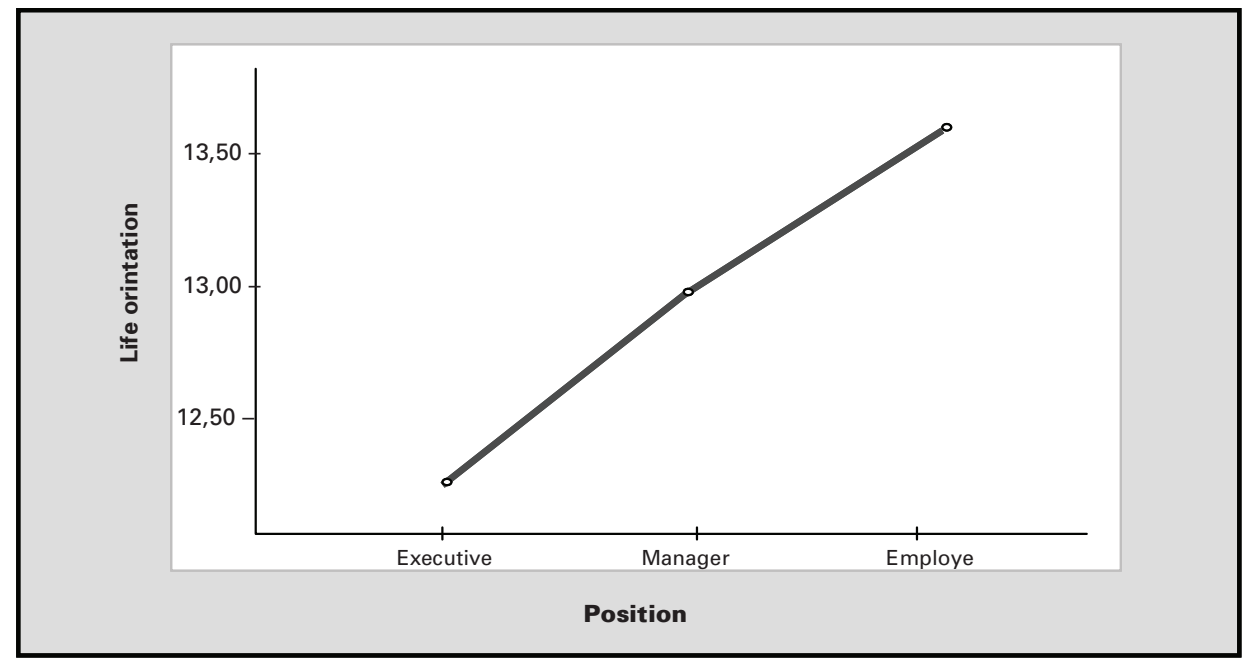


Eva Boštjančič

Job satisfaction, life orientation

and perception of family role

Table 1: Correlation between type of satisfaction and demographic variables

\begin{tabular}{|l|c|c|c|c|}
\hline \multirow{2}{*}{} & \multicolumn{4}{|c|}{ Type of satisfaction } \\
\cline { 2 - 5 } & Career & Parental & Leisure time & Partner \\
\hline Age & $\bullet 0.029$ & $\bullet 0.086^{*}$ & $\bullet 0.091^{* *}$ & $\bullet 0.259^{* *}$ \\
Seniority & $\bullet 0.033$ & $\bullet 0.084^{*}$ & $\bullet 0.080^{* *}$ & $\bullet 0.239^{* *}$ \\
Education level & $0.235^{* *}$ & 0.039 & $0.059^{*}$ & $0.062^{*}$ \\
Profession & 0.028 & 0.043 & $\bullet 0.071^{*}$ & 0.003 \\
Professional status & 0.004 & 0.003 & $0.090^{* *}$ & $0.090^{* *}$ \\
\hline
\end{tabular}

${ }^{*} p<0.05 .{ }^{*} p<0.01$

As shown in Table 1 the correlations between types of satisfaction are statistically significant, but relatively low. Participants with the highest level of education are more satisfied with their careers $(r=0.23 ; p<0.01)$. Higher age and seniority are linked to lower parental satisfaction, and lower satisfaction with partners and leisure-time quality. Women whose work entails more responsibility are more satisfied with their leisure time and partners.

Partner. Women who currently have a partner (compared with singledivorced women group) are more satisfied with their lives $(F(1,1001)=39.92$; $p<0.01) .50 .1 \%$ state they share household chores equally; $45.2 \%$ say they themselves do $70 \%$ of work, which leaves 30\% for the partner. Single and divorced women find more satisfaction in balancing work and leisure time $(F(1$, $1177)=14.71 ; p<0.01)$. The satisfaction with this role is not statistically significant in relation to life orientation and decline part of hypothesis $\mathrm{H}_{2}$.

Parenthood. The majority of women believe that the right time for motherhood is when they want to have children $(65 \%)$ or up to age 30 , when women are not yet in executive positions (28\%). To the followed questions answered only women that already had experiences as a mother. The majority of women decided to become mothers prior to turning 30, when they were not yet in executive positions (51\%). $25 \%$ had an unplanned pregnancy, 13\% gave birth to their first child while they were college students, and $10 \%$ had children later, after they had accomplished 
what they desired at work. The number of children affects women's lives and their way of thinking. Women that have more children have less time for themselves $(\delta=$ $-0.21 ; p<0.01$ ). Such women also spend less time with their children (probably because their time is divided between several children) $(\delta=-0.59 ; p<0.01)$. Women with more children are more pessimistic $(\delta=0.08 ; p<0.01)$ but there were any statistical significant connection between perception of motherhood role and life orientation of participants. This finding does not support part of hypothesis $\mathrm{H}_{2}$. On the other hand more happier women spend more time women spend with their children $(\delta=0.12 ; p<0.01)$.

Women without children are the most satisfied with their partners; the least satisfied in this regard are women with two children. Women with one child, or three or more, find themselves in the middle regarding partner satisfaction $(F(3$, $1008)=19.99 ; p<0.01)$. Women without children are the most satisfied with their leisure time, and women with children less so $(F(3,1184)=17.91 ; p<0.01)$. Women with three children are the most satisfied with life in general, followed by women without children and with two children. The least satisfied in this regard are women with only one child $(F(3,1092)=4.44 ; p<0.01)$.

\section{Figure 4: Association between number of children and partner} relationship satisfaction

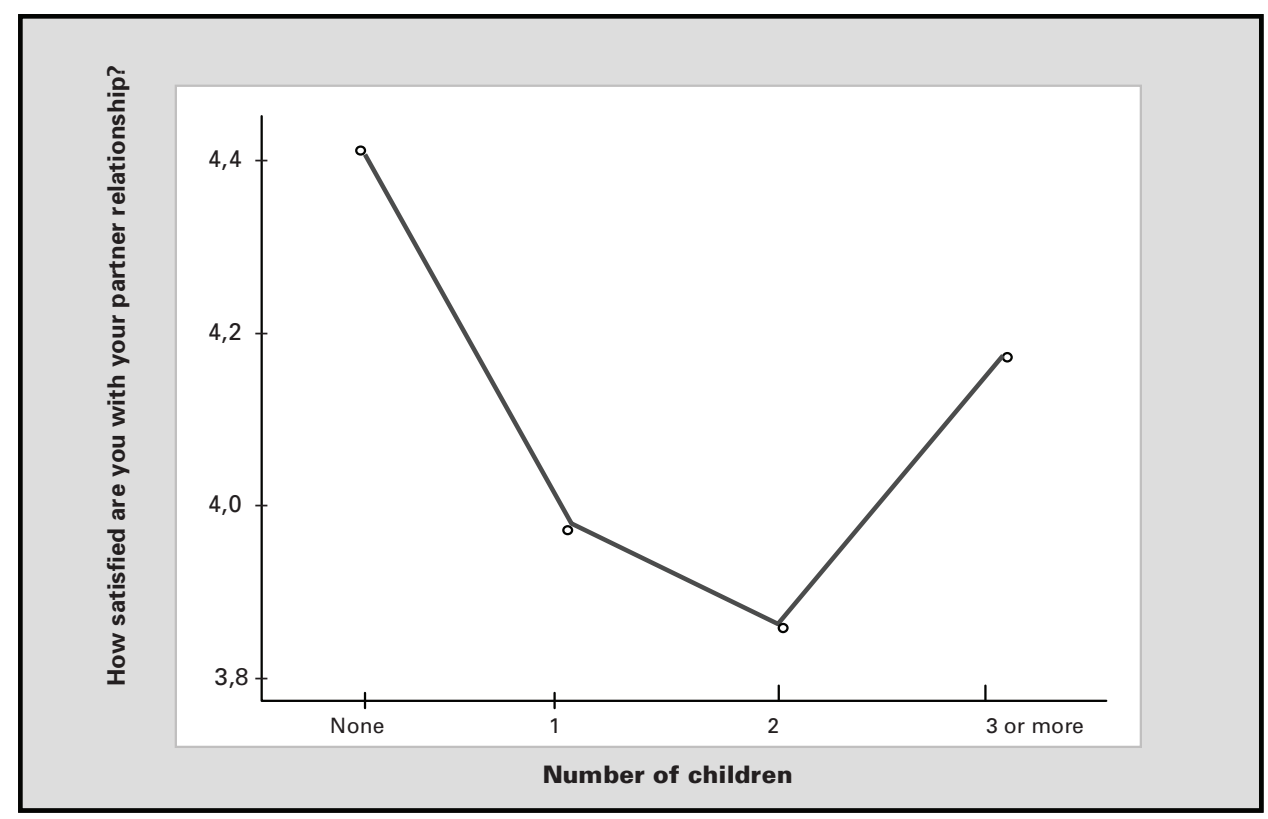


Eva Boštjančič

Job satisfaction, life orientation

and perception of family role

Figure 5: Association between number of children and life satisfaction

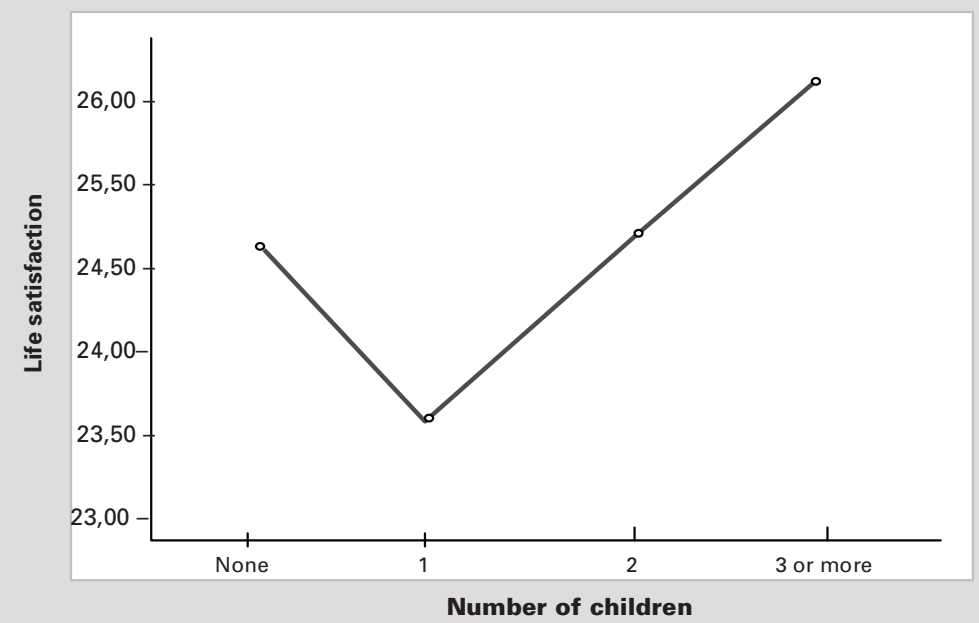

The age of children also plays an important role. The older children are, the more time women devote to household chores (probably because they have more time on their hands). With the age of children, both parental satisfaction $(F(3,814)=3.33$; $p<$ $0.01)$ and partner satisfaction $(F(3,750)=6.90 ; p<0.01)$ decrease. However, once children find a job or perhaps leave home (after college), partner satisfaction increases again. Life satisfaction also decreases, but goes up again when children start to work $(F(3,748)=10.93 ; p<0.01)$

Figure 6: Association between children's ages and satisfaction with maternal role

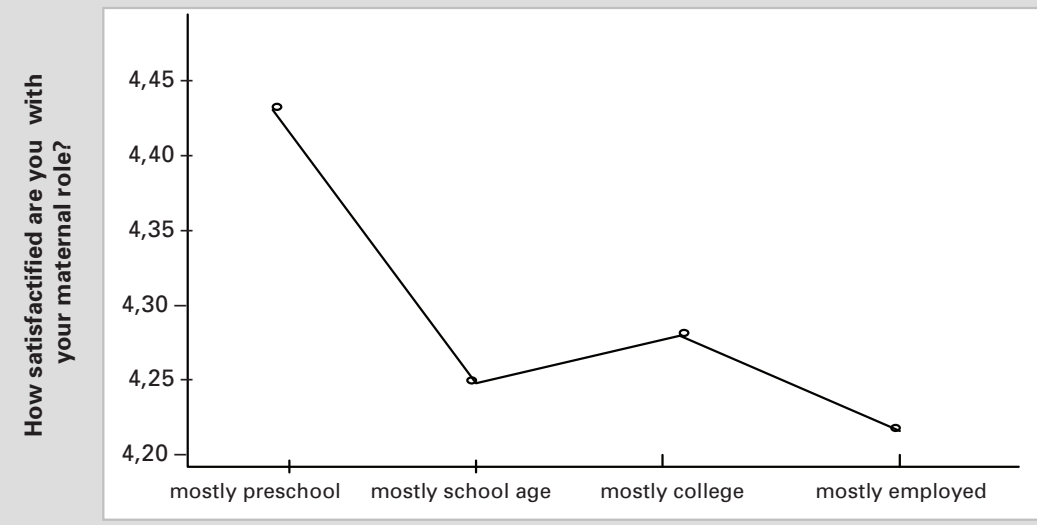

Age of children 
Figure 7: Association between children's ages and partner relationship satisfaction

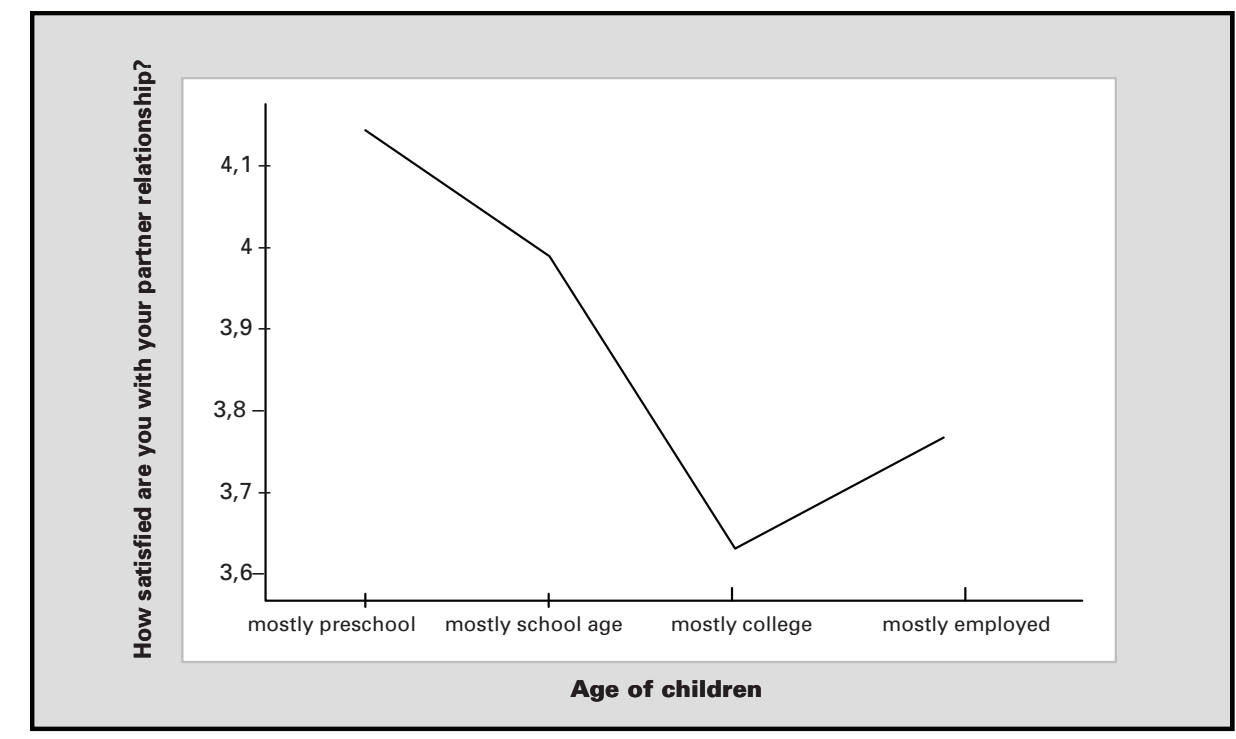

Figure 8: Association between children's ages and life satisfaction.

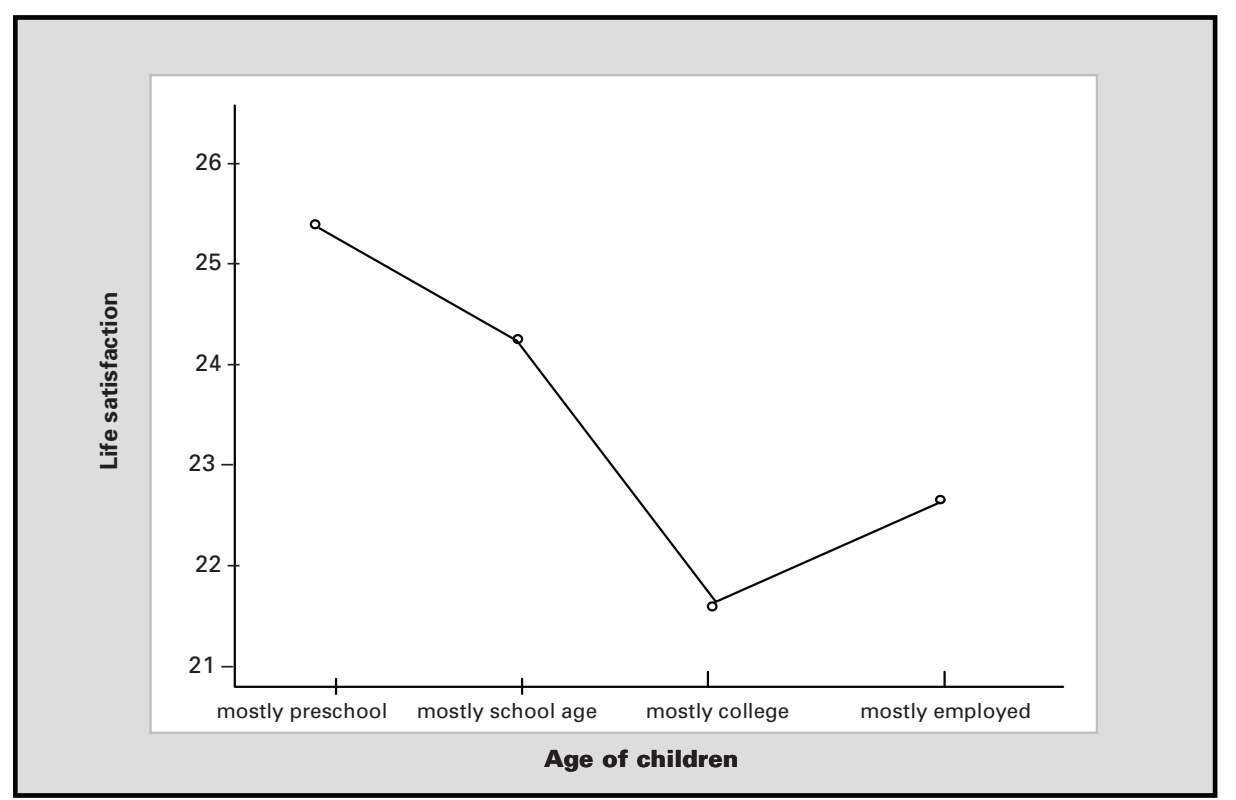

Number of roles. Finally, in order to establish which factors affect the number of roles employed women have, three sets of variables were included 


\section{Eva Boštjančič \\ Job satisfaction, life orientation and perception of family role}

in the hierarchical regression analysis. The first variables are education level and career satisfaction, both pertaining to job satisfaction. The second part includes variables linked to private life satisfaction, and the third includes two variables linked to individuals' general orientation: life satisfaction and life optimism or pessimism.

Table 2: Hierarchical regression analysis model: influence of independent research variables on the number of roles employed women play

\begin{tabular}{|c|c|c|c|c|}
\hline Model & & 1 & 2 & 3 \\
\hline 1 & $\begin{array}{l}\text { Level of education } \\
\text { Career satisfaction }\end{array}$ & $\begin{array}{l}0.13^{* *} \\
0.01\end{array}$ & $\begin{array}{l}0.13^{* *} \\
0.02\end{array}$ & $\begin{array}{l}0.12^{* *} \\
0.01\end{array}$ \\
\hline 2 & $\begin{array}{l}\text { Satisfaction with maternal role } \\
\text { Leisure-time satisfaction } \\
\text { Partner relationship satisfaction }\end{array}$ & & $\begin{array}{l}0.08^{*} \\
\bullet 0.09^{*} \\
\bullet 0.03\end{array}$ & $\begin{array}{l}0.08 \\
\bullet 0.09^{*} \\
\bullet 0.02\end{array}$ \\
\hline 3 & $\begin{array}{l}\text { Life orientation } \\
\text { Life satisfaction }\end{array}$ & & & $\begin{array}{l}\bullet 0.09^{*} \\
\bullet 0.03\end{array}$ \\
\hline & $\begin{array}{l}R^{2} \\
F\end{array}$ & $\begin{array}{l}0.02 \\
6.42^{* *}\end{array}$ & $\begin{array}{l}0.03 \\
3.99 * *\end{array}$ & $\begin{array}{l}0.03 \\
3.48^{* *}\end{array}$ \\
\hline
\end{tabular}

${ }^{*} p<0.05 .{ }^{* *} p<0.01$.

Table 2 shows that the number of roles women assumes in their lives is primarily influenced by their education and partially by satisfaction with their maternal role. Optimism also positively correlates with the number of roles women identy as their own and partly support hypothesis $\mathrm{H}_{3}$.

\section{Discussion}

In modern society, women are caught between several roles. The society or women's immediate surroundings expect them to perform each role successfully. This study seeks to answer the following question: How are the roles of working women linked to their personal characteristics and other 
demographic factors? Another question arises as well: Is there a conflict in women balancing family and work?

It is interesting that a great number of the questionnaires distributed online were completed and returned. This is a good indicator and can forecast the future orientation of psychological research - in areas that allow such methods, of course. Such an approach makes possible broader and international studies. According to Davis (1999), the use of the Internet enables access to a greater sample of participants, who then participate in data collection; in turn, this is faster and guarantees complete anonymity. Anonymity can have a positive influence on the tendency to give socially desirable answers. At the same time, as confirmed in the study on filling out personality questionnaires via the Internet (Kveton et al., 2007), such a method is a reliable one and will be useful in the future.

The first question is how life orientation, whether optimism or pessimism, influences working women's views. Optimists expect positive things to happen. They have faith in themselves and put a lot of effort into the work they do. In the research it was established that the most optimistic participants were female executives. Descending the hierarchical ladder decreases optimism; this is perhaps linked to lower income, unfulfilled wishes, or problems encountered at the outset or during the career. Because optimism is a relatively stable personality trait, career counseling should caution people in advance on the advantages, challenges, and disadvantages of a particular job as well as which personal traits are expected given the nature of work.

Does work influence satisfaction? As early as 1983, a study by Freudiger revealed that there are small differences between life satisfaction among women that used to be employed, were employed at the time, and had never been employed. Employed Japanese women with more children perceived themselves as effective parents and reported greater life satisfaction (Holloway, 2006). Such parallels are perhaps difficult to transpose into the Slovenian or European context; however it can be stated with great certainty that satisfaction at work is linked to different external and internal factors. In this study, the most common answers to the question "What does being employed mean to you?" were personal fulfillment $(n=893)$, social security $(n=866)$, and, on the other hand, burden and stress $(n=190)$, giving up many things $(n=116)$, and being a woman in a man's world $(n=92)$.

According to DeFour and Brown (2006), good care for the household and work satisfaction influence private life satisfaction and age predicts career 
Eva Boštjančič

Job satisfaction, life orientation

and perception of family role

satisfaction. As demonstrated, women in Slovenia are most satisfied with their maternal role and partners, and less satisfied with their career and the quality of their leisure time. Motherhood and the partner relationship can be combined under the common denominator of a factor that women can directly influence. On the other hand, career and leisure time are influenced by several external factors, such as relations at work, opportunities for promotion, and physical working conditions. Satisfaction with the partner relationship increases with age, in contrast to satisfaction with the parental role and leisure time. Education level is often an important demographic variable. This study has shown that a higher level of education is linked to career satisfaction; nevertheless, it negatively influences leisure time spent away from work. This connection makes sense because higher education enables more rapid promotion followed by higher and more responsible positions, which in return leaves less time for quality leisure. At the same time, career satisfaction strongly correlates with life satisfaction $(r=0.41 ; p<0.01)$, which illustrates the mutual influence of these two variables. In practice, this can be seen as all-round care for employees as a workforce and as individuals that live their family and professional lives in parallel. Satisfaction at work will be reflected in general satisfaction; at the same time, the order of private life will be reflected in career satisfaction (i.e., job satisfaction).

Women give birth regardless of the differences and similarities between genders. The experiences and recommendations of the 1,298 women that participated in this study show that it is best and easiest to have children up to age 30 or prior to assuming an executive position. Optimism increases with the number of children (with the first optimism plummets, but then increases again). DeFour and Brown (2006) came to a similar conclusion when they established that mothers that see their children as the greatest joy in life report higher family satisfaction. The women in this study connect their role as mothers with personal fulfillment $(n=744)$, giving up many things $(n=396)$, and being a woman $(n=365)$.

The results presented here should be summarized for the particular group of women employed at different hierarchical levels in an organization. Leading managers, such as directors, businesswomen, and board members, are (as expected) satisfied with their careers and the successes they have achieved in their professional lives. This agrees with the findings of Crompton and Lyonette (2004), who say that higher positions offer more positive opportunities: promotion, a sense of responsibility, self-respect, financial independence, 
and so on. As established earlier, such satisfaction correlates with life satisfaction; however, women in this group are characterized by only moderate optimism. The reasons for such a world view can be found in the fact that they bear great responsibilities and are well informed and familiar with the current economic and political situation. Leisure-time satisfaction is high as well, which correlates with better financial opportunities, making possible quality and more expensive activities and help with the household. All of this leaves time for hobbies and various forms of relaxation. On the other hand, these women are dissatisfied with their maternal role, for which they probably lack time and energy. A 1987 study (Pietromonaco, Manis, \& Markus) revealed that careeroriented women with full-time employment are more satisfied with themselves and their lives than women that only work part-time or are unemployed. When describing themselves, these women list numerous characteristics in connection with their positions.

Female managers are usually bound directly to the organization, at the same time being responsible for their subordinates' results as well as the performance of all tasks assigned by their superiors. These are women that have already advanced in their careers; nevertheless, their further promotion depends on them alone - their management, motivation, and delegation skills, focus on results and achievements, and so on. This study shows that this group of women is fairly satisfied with their career and life, but sees life least optimistically. Having to prove oneself at work leaves little time for household chores and relaxing hobbies. Such women are primarily fulfilled by the great satisfaction found in motherhood and in their partners. In practice, the findings primarily reveal a need for greater attention to this group. Women in this group need more relaxation, earned leisure time, and perhaps greater concern for their private lives on the part of their superiors. One suggestion is clearer career planning, allowing them to see the reward (i.e., promotion) for achieving the goals set. Small tokens of appreciation from an employer can help increase effectiveness at work and, indirectly, career and life satisfaction.

The final group of women is as important as the rest and includes female employees without managerial authority, who are pessimistic but satisfied with their lives. What are the reasons for this combination? These are mostly employees without high ambitions, who like to do routine everyday work and do not seek greater authority or responsibility. Hence, they remain in their positions; however, lower positions entail less pay. Less money also means lower material security. These women are less satisfied with their careers, 
Eva Boštjančič

Job satisfaction, life orientation

and perception of family role

their partners, and the quality of their leisure time. Limited leisure time may again be linked to lower income.

Going back to the theories of multiple roles, it has been established that women that assume several roles are slightly more optimistic $(r=-0.067 ; p<$ $0.05)$. Multiple roles correlate positively with parental satisfaction $(r=0.07 ; p<$ $0.05)$ and negatively with partner relationship $(r=-0.10 ; p<0.05)$ and the quality of leisure time $(r=-0.16 ; p<0.01)$. The correlations are low, not making it possible to confirm the stress role theory or the theory of role accumulation.

What next? What are the opportunities for women's development? Newspaper articles and studies in this area (Avber'ek, 2006) currently show that the share of female managers is between 3\% and $20 \%$ in any particular organization. There are several reasons for this low percentage (Kanjuo Mrčela, 1996): it can be seen as an underestimation of women's management style, the unbreakable glass ceiling, a lack of role models, sexual harassment, family obligations, frequently limited geographical mobility, traditional prejudices, including emotional instability and absenteeism, and so on. On the other hand, this is an area that is being increasingly discussed, studied, and written about. There is a gradual process of awareness-raising taking place; slowly, but steadily, facts are being brought to light, and numbers are dispelling myths, discrimination, and false beliefs. All this observations are present in all sectors public, economic, healthcare etc. The same challenges and same obstacles motivate women in Slovenia to research, to write and to discuss about the topics mentioned above.

This study has continually raised new questions that could provide valuable answers for understanding the lives of working women and at the same time possibly improving social and economic policies in employment:

- Which factors influence women's decisions to choose a professional or management career?

- What are the advantages of employment in public sector? Is there a work motivation different?

- What is the influence of women's immediate and extended family and family patterns on career planning?

- And last but not the least: Are findings in this research unique to women or whether they characterize men, too? 
Eva Boštjančič

Job satisfaction, life orientation and perception of family role

Eva Boštjančič je asistentka na Oddelku za psihologijo Filozofske fakultete Univerze v Ljubljani. S področja psihologije potrošnika je diplomirala leta 1996, nato pa jo je delovno mesto svetovalke za področje kadrov usmerilo k raziskovanju procesa vodenja in čustvene inteligentnosti. Leta 2002 je magistrirala z nalogo Osebnostne značilnosti uspešnih managerjev, 2008 pa si je z dizertacijo Vpliv vedenja in motivov vodje na pripadnost, delovno učinkovitost, motivacijo in delovno zadovoljstvo zaposlenih pridobila naziv doktorice znanosti. Leta 2003 je pridobila naziv asistentke za predmet Psihologija dela in organizacije na ljubljanski Filozofski fakulteti in od februarja 2004 vodi vaje iz tega predmeta. Leta 2007 je ponovno izvoljena za to funkcijo. V zadnjem obdobju skrbi tudi za koordinacijo Vzporedno si je nabrala tudi številne izkušnje kot svetovalka na področju kadrovskega svetovanja, ki vključuje direktno iskanje in selekcijo vodilnih in visoko strokovnih kadrov, izvaja analize delovnega zadovoljstva, psihološko svetovanje managerjem, merjenje organizacijske klime in kulture, uvajanje letnih razgovorov, učinkovito vodenje kadrovske funkcije v podjetju, pomoč pri konfliktnih/kriznih situacijah in svetuje na področju razvoja kadrov. 


\section{Eva Boštjančič \\ Job satisfaction, life orientation \\ and perception of family role}

\section{References}

- Avberšek, A. (2006). Ženske na vodilnih managerskih položajih v delni'kih družbah v Sloveniji - empirična analiza, neobjavljeno diplomsko delo. Ljubljana. Ekonomska fakulteta.

- Barnett, R. C. (1998). Toward a review and reconceptualization of the work/family literature. Genetic, Social, and General Psychology Monographs, 124, 125-182.

- Barnett, R. C., \& Hyde, J. S. (2001). Women, men, work, and family: An expansionist theory. American Psychologist, 56, 781-796.

- $\quad$ Baruch, G. K., Biener, L., \& Barnett, R. C. (1987). Women and gender in research on work and family stress. American Psychologist, 42, 130-136.

- Crouter, A. (1984). Spillover from family to work: The neglected side of the work-family interface. Human Relations, 37, 425-442.

- Davis, R. N. (1999). Web-based administration of a personality questionnaire: Comparison with traditional methods. Behavior Research Methods, Instruments, \& Computers, 31, 572-577.

- DeFour, D. C., \& Brown, T. M. (2006). Attitudes toward maternal roles and effects on life satisfaction: Black, Hispanic, and White models. Journal of African American Studies, 20(3), 3-18.

- Diener, E., Emmons, R. A., Larsen, R. J., \& Griffin, S. (1985). The Satisfaction with Life Scale. Journal of Personality Assessment, 49, 71-75.

- Freudiger, P. (1983). Life satisfaction among three categories of married women. Journal of Marriage and the Family, 45(1), 213-219.

- Frone, M. R. (2003). Work-family balance. In J. C. Quick \& L. E. Tetrick (Eds.), Handbook of occupational health psychology (pp. 143-162). Washington, DC: American Psychological Association.

- Diener, E., Emmons, R. A., Larsen, R. J. and Griffin, S. (1985). The Satisfaction With Life Scale. Journal of Personality Assessment, 49, 71-75.

- Greenhaus, J. H., \& Parasuraman, S. (1999). Research on work, family, and gender: Current status and future directions. In G. N. Powell (Ed.), Handbook of gender and work (pp. 391-412). Newbury Park, CA: Sage.

- Grzywacz, J. G. (2000). Work-family spillover and health during midlife: Is managing conflict everything? American Journal of Health Promotion, 14, 236-243.

- Haas, L. (1999). Families and work. In M. Sussman, S. K. Steinmetz, \& G. W. Peterson (Eds.), Handbook of marriage and family, 2nd ed. (pp. 571-612). New York: Plenum Press.

- Kanjuo Mrčela, A. (1996). Ženske v menedžmentu. Ljubljana: Enotnost.

- Kirchmeyer, C. (1992). Nonwork participation and work attitudes: A test of scarcity vs. expansion models of personal resources. Human Relations, 45, 775-795. 


\section{Eva Boštjančič \\ Job satisfaction, life orientation and perception of family role}

- Kveton, P., Jelinek, M., Klimusova, H., \& Voboril, D. (2007). Data collection on the internet: evaluation of web-based questionnaires. Studia Psychologica, 49, 81-88.

- Levenson, R. W., Carstensen, L. L., \& Gottman, J. M. (1993). Long-term marriage: Age, gender, and satisfaction. Psychology \& Aging, 8, 301-313.

- Malačič, J. (2009). Trg dela in zaposlenost v javnem sektorju v Sloveniji. Retrieved May 10, 2010, from http://www.stat.si/StatDnevi2009/Docs/Mala\%C4\%8Di\%C4\%8DTrg\%20dela_prispevek.pdf.

- $\quad$ Pietromonaco, P. R., Manis, J., \& Markus, H. (1987). The relationship of employment to selfperception and well-being in women: A cognitive analysis. Sex Roles, 17(7/8), 467-477.

- Rothbard, N. P. (2001). Enriching or depleting? The dynamics of engagement in work and family roles. Administrative Science Quarterly, 46, 655-684.

- $\quad$ Ruderman, M. N., Ohlott, P. J., Panzer, K., \& King, S. N. (2002). Benefits of multiple roles for managerial women. Academy of Management Journal, 45, 369-386.

- Scarr, S., Phillips, D., \& McCartney, K. (1989). Working mothers and their families. American Psychologist, 44, 1402-1409.

- Scheier, M. F., Carver, C. S., \& Bridges, M. W. (1994). Distinguishing optimism from neuroticism (and trait anxiety, self-mastery, and self-esteem): A re-evaluation of the Life Orientation Test. Journal of Personality and Social Psychology, 67, 1063-1078.

- Schoon, I., Hansson, L., \& Salmela-Aro, K. (2005). Combining work and family life: Life satisfaction among married and divorced men and women in Estonia, Finland, and the UK. European Psychologist, 10, 109-319.

- Stoltz-Loike, M. (1992). The working family: Helping women balance the roles of wife, mother, and career woman. The Career Development Quarterly, 40(3), 244-256.

- Summer, H. C., \& Knight, P. A. (2001). How do people with different attachment styles balance work and family? A personality perspective on work-family linkage. Journal of Applied Psychology, 86, 653-663.

- $\quad$ Tiedje, L. B., Wortman, C. B., Downey, G., Emmons, C., Biernat, M., \& Lang, R. (1990). Women with multiple roles: Role-compatibility perceptions, satisfaction, and mental health. Journal of Marriage and the Family, 52, 63-72.

- Tompson, H. B., \& Werner, J. M. (1997). The impact of role conflict/facilitation on core and discretionary behaviors: Testing a mediated model. Journal of Management, 23, 583-601.

- Vertot, N. (2008). Ženske v Sloveniji. Retrieved February 4, 2010, from http://www.stat. si/novica_prikazi.aspx?id=1497.

- Wayne, J. H., Musisca, N., \& Fleeson, W. (2004). Considering the role of personality in the work-family experience: Relationship of the big five to work-family conflict and facilitation. Journal of Vocational Behavior, 64, 108-130 
Eva Boštjančič

Job satisfaction, life orientation

and perception of family role

POVZETEK

DELOVNO ZADOVOLJSTVO, ŽIVLJENJSKA USMERJENOST IN ZAZNAVANJE DRUŽINSKE

VLOGE - PRIMERJAVA MED ŽENSKAMI

ZAPOSLENIMI V JAVNI UPRAVI IN GOSPODARSTVU

$\mathrm{V}$ raziskavi smo se usmerili $\mathrm{k}$ vlogam zaposlene ženske, ki je vpeta $\mathrm{v}$ različne socialne, družbene in intimne vloge. Statistični podatki kažejo, da je $\vee$ Sloveniji zaposlenih $61,8 \%$ žensk, kar je več kot v povprečju v EU, kjer je zaposlenost žensk 57,2\%. V javnem sektorju je delež žensk večji od dveh tretjin. Veča se tudi delež prebivalstva vpisanega na študij na terciarni ravni, pri čemer je med vpisanimi $\vee$ višješolske, visokošolske in univerzitetne programe kar 58,3\% žensk. Tudi med diplomiranci na terciarni ravni leta 2006 je bilo pri nas 61,9\% žensk. Položaj žensk na trgu delovne sile kljub temu ni enakovreden - zaposlenih je več moških kot žensk, več žensk kot moških je brezposelnih, ženske tudi zaslužijo na uro približno $15 \%$ manj kakor moški, pri doseganju visokih položajev pa imajo več težav kakor moški.

Pretekle raziskave kažejo, da so zaposlene ženske manj depresivne, bolj duševno zdrave in ob pojavu stresnih dogodkov redkeje razvijejo psihopatološko simptomatiko kot nezaposlene ženske. Napredovanje na višja delovna mesta nudijo ženskam več pozitivnih priložnosti - napredovanje, občutek odgovornosti, samospoštovanje, finančno neodvisnost, hkrati tudi pozitivno vplivajo na njihove vloge $v$ socialnem, ekonomskem in zasebnem življenju. Če se morajo odločati med različnimi vlogami, pogosteje posvečajo čas družini in službi, redkeje si ga vzamejo zase in za sprostitev. Spremembe v poklicnih vlogah imajo večji vpliv na duševno zdravje žensk brez družine. Prav tako so ženske s predšolskimi otroki manj pod stresom, če hodijo v službo.

Večina žensk igra $v$ obdobju odraslosti več vlog, ki se povezujejo z njenim privatnim (mati, žena, hči, gospodinja) ali službenim življenjem (zaposlena, vodja, usmerjevalka). Odnos med vlogami so v preteklosti raziskovalci obdelovali predvsem z vidika negativnih posledic, konflikta med vlogami (teorija stresnih vlog; Schoon, Hansson in Salmela-Aro, 2005), sodobni trendi pa narekujejo pogled s pozitivne strani, oz. kako preplet 
različnih vlog bogati, pozitivno krepi, vzpodbuja in omogoča razvoj posameznice (teorija akumilacije vlog; v Schoon in dr., 2005).

$\checkmark$ raziskavi smo si postavili tri hipoteze:

$\mathrm{H}_{1}$ : Ženske zaposlene $\mathbf{v}$ javnem sektorju dosegajo nižje delovno zadovoljstvo kot ženske zaposlene $\mathbf{v}$ gospodarstvu.

$\mathrm{H}_{2}$ : Življenjska usmerjenost (optimizem - pesimizem) žensk se pozitivno povezuje $z$ njenim pogledom na kariero, otroke in zaznano vlogo partnerja.

$H_{3}$ : Obstaja pozitivna povezanost med multiplimi vlogami ženske, optimizmom in njenim življenjskim zadovoljstvom.

Zbiranje podatkov za raziskavo je potekalo poleti 2008. Vprašalnik, ki je vseboval vprašanja o demografskih podatkih, zadovoljstvu z različnimi vlogami (materinstvo, konjički in prosti čas, zaposlitev, partnerstvo), zadovoljstvu z življenjem (SWLS) in vprašalnik optimizma (LOT-R) je bil dostopen na internetu in distribuiran preko elektronske pošte. $\mathrm{V}$ raziskavi je sodelovalo 1298 zaposlenih žensk, katerih povprečna starost je bila 35,6 let. Večina udeleženk je bila poročena $(48 \%)$ ali $v$ partnerskem odnosu (35\%). Največ udeleženk je imelo višjo, visoko ali univerzitetno izobrazbo (43\%). $49 \%$ jih je bilo zaposlenih $v$ gospodarstvu, $51 \%$ v javnem sektorju.

Rezultati so pokazali, da so najbolj zadovoljne ženske zaposlene na področju zdravstva in $v$ farmacevtski panogi, nato sledijo zaposlene $v$ šolstvu in gospodarstvu, najbolj nezadovoljne pa so zaposlene $v$ državni upravi.

Najbolj so optimistične vodilne na vodilnih položajih. S spuščanjem po hierarhični lestvici navzdol pa se optimizem manjša, kar je morda povezano z nižjimi dohodki, z neizpolnjenimi željami, s težavami, ki jih lahko ženska srečuje na začetku ali tekom karierne poti.

$\mathrm{Na}$ vprašanje Kaj vam pomeni biti zaposlena ženska? so udeleženke raziskave najpogosteje navajale odgovore: osebno izpopolnitev $(N=893)$, socialno varnost ( $N=866)$, na drugi strani pa breme in stres $(N=190)$, veliko odrekanja ( $N=116)$ in biti ženska v svetu moških $(N=92)$.

Ugotovili smo, da so ženske $v$ Sloveniji najbolj zadovoljne s svojo materinsko vlogo in partnerjem, manj zadovoljne pa so s kariero in s kvaliteto preživljanja prostega časa. S starostjo zadovoljstvo z odnosom, ki ga imata partnerja med seboj, narašča, na drugi strani pa upada zadovoljstvo 
Eva Boštjančič

Job satisfaction, life orientation

and perception of family role

s starševsko vlogo in preživljanjem prostega časa. Stopnja izobrazbe pogosto igra pomembno demografsko spremenljivko. $V$ naši raziskavi se je pokazalo, da se višja stopnja izobrazbe povezuje z zadovoljstvom s kariero in negativno s prostim časom, ki ga preživljamo izven službe. Hkrati pa se zadovoljstvo s kariero pomembno pozitivno povezuje z zadovoljstvom z življenjem, kar nam lahko govori o medsebojnem vplivanju teh dveh spremenljivk.

Glede na izkušnje udeleženk raziskave in njihova priporočila, je najbolje in najlaže imeti otroke do 30 . leta, oz. ko še nisi na vodilnem delovnem mestu. S številom otrok optimizem narašča (pri prvem otroku optimizem drastično upade, nato pa narašča), zanimiva pa je ugotovitev, da zadovoljstvo s partnerskim odnosom upade z rojstvom prvega otroka, pri drugem se stvari še poslabšajo, medtem ko tretji otrok morda prinese večjo tolerantnost ali morda večje sodelovanje ter razumevanje med partnerjema in $\mathrm{s}$ tem višje partnersko zadovoljstvo. Ženske $v$ naši raziskavi svojo vlogo matere najpogosteje povezujejo z osebno izpopolnitvijo, veliko odrekanja in biti ženska.

Povzemimo predstavljene rezultate še za posamezno skupino žensk zaposlenih na različnih hierarhičnih nivojih $v$ organizaciji. Vodilne menedžerke so dokaj pričakovano zadovoljne s svojo kariero in uspehi, ki so (si) jih uspele dokazati $v$ svojem profesionalnem življenju. Pri njih opazimo tudi visoko stopnjo zadovoljstva s preživljanjem prostega časa, na drugi strani pa so nezadovoljne $z$ materinsko vlogo, za katero jim verjetno zmanjkuje časa in energije.

Ženska na vodstvenem delovnem mestu, ki je $v$ organizacijo ponavadi vpeta zelo direktno, hkrati pa odgovorna za rezultate svojih podrejenih in odgovorna za izvedene naloge, ki ji jih dodeli njen nadrejeni ali nadrejena. $\checkmark$ pričujoči raziskavi je ta skupina žensk dokaj zadovoljna s kariero in življenjem in na življenje gleda najmanj optimistično. Zaradi dokazovanja na delovnem mestu ima manj časa za gospodinjska opravila in hobije, ki bi ji omogočali sprostitev. Izpopolnjuje jo predvsem visoko zadovoljstvo z materinstvom in partnerjem.

In še zadnja skupina žensk, ki pa ni najmanj pomembna. Ženske brez vodstvenih pooblastil, zaposlene, so pesimistične, a zadovoljne z življenjem. Kje so razlogi za takšno kombinacijo? Veliko je zaposlenih, ki nima visokih ambicij, ki rade opravljajo vsakodnevna rutinska opravila in si ne žele večjih pristojnosti in odgovornosti. Tako vztrajajo na svojih položajih, hkrati pa so na nižjih delovnih mestih tudi slabše plačani. Manj denarja 
pomeni tudi nižjo materialno varnost. So bolj nezadovoljne s kariero, partnerjem in kvaliteto preživljanja prostega časa.

Vrnimo se nazaj k teorijam o prepletu različnih vlog. Ugotovili smo, da ženska, ki v življenju igra več vlog hkrati, je malo bolj optimistična, drugače pa se multiplost vlog pozitivno povezuje s starševskim zadovoljstvom ter negativno $s$ partnerskim odnosom in $s$ kvaliteto preživljanja prostega časa. Korelacije so nizke, tako, da ne moremo potrditi ne teorije stresnih vlog in ne teorije akumulacije vlog. 